\title{
THE DETERIORATION OF WEAKLY VERTICAL LINKAGES IN TRA CATFISH INDUSTRY IN AN GIANG PROVINCE, VIETNAM
}

\author{
Nguyen Van Phuong, \\ The School of Business, International University, Vietnam
}

Bui Thanh Thuy Van,

The School of Business, International University, Vietnam

Huynh Thi Ngoc Hien,

Vietnam - Netherland Programme, Vietnam

(Received: 12/02/14; Revised: 26/03/14; Accepted: 05/04/14)

\begin{abstract}
This study analyzes the vertical linkage effectiveness between fish farmers and processing companies on the mutual beneficial relationship, knowledge transfer, quality standards, embedded services, and payment before the United State (US) Department of Commerce has decided to impose new rates of antidumping taxes on tra (Pangasius) fish fillets imported from Vietnam. After conducting the first survey of 70 fish farmers and five in-depth interviews with directors of processing enterprises, representatives of provincial authority, and experts in the field during March and April of 2012 in An Giang province, Vietnam, we found that the mutual beneficial relationship was the most influent factor to vertical linkage effectiveness. However, after new rates of antidumping duties were imposed, we conducted the second survey of 17 in-depth interviews with 12 fish farmers, four local officers and one expert during April and June of 2013 in An Giang province, and recognized that almost all vertical linkages with processing companies to export to the US market have been deteriorated and dispersed.
\end{abstract}

Keywords: effectiveness, deteriorate vertical linkage, tra catfish.

\section{Introduction}

The statement "export of aquatic products is one of three major economic programs" in Vietnam Communist Party's Resolution in 2009 has been and will be a strategic key in economic integration and globalization of our country. According to The Vietnam Association of Seafood Exporters and Producers (VASEP) in Quarter I, 2012, tra catfish export occupies a large percentage of more than $28 \%$ of total aquatic export turnover contributing a significant percentage to the country's GDP. Tra catfish farming is a breakthrough agricultural industry and a very high economic value because only 6,000 hectares of tra catfish farming return on US\$1.5 billion in 2009 (Source: VASEP)

An Giang Province is the cradle of Pangasius Hypophthalmus (tra catfish) farming in Mekong River Delta (MRD). From late $20^{\text {th }}$ to early $21^{\text {st }}$ century, tra catfish aquaculture, processing and export industry in this region has quickly developed and created a good reputation in MRD and Vietnam in general. Until now, An Giang Province has reached over 1,200 hectares of tra catfish aquaculture in $2011(1,394$ hectares in 2007) - equivalent $20 \%$ of total tra catfish farming area in Vietnam. This contributes greatly to the economic development of An Giang Province and MRD. 


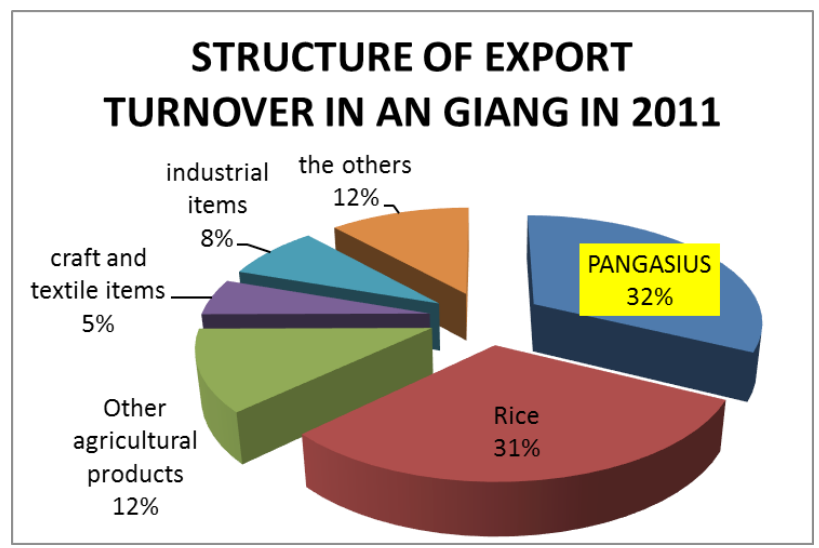

Source: An Giang statistical yearbook 2011

Figure 1. Structure of export turnover in An Giang province in 2011

In recent years, An Giang's tra catfish aquaculture has been growing and primarily focusing on export market $(70 \%$ of annual output). Alongside this trend, export turnover of tra catfish has been increasing and reached $32 \%$ of An Giang's total export turnover in 2011. As a result, tra catfish industry has contributed to the restructure of agricultural sector of An Giang Province. Since 2005, An Giang's tra catfish has been exported to most of the largest markets such as EU, US, ASEAN, Russian, Egypt, etc. (An Giang Statistical yearbook 2011).

Besides the above achievement, there are still a lot of risks remaining in this industry. Under specific circumstances of An Giang Province - one of the provinces with the largest tra catfish production in MRD, tra catfish market fluctuates over time and confronts many challenges such as strict food safety requirements, other competitors, material shortage, antidumping law when exporting to US and EU markets, etc. Due to this unstable growth, tra catfish farming and processing in An Giang frequently faces the problems of shortage or surplus of fish raw materials, affecting export turnover of tra catfish, and even causing bankruptcy to a number of farmers and small enterprises. There is an imbalance in production-consumption in the industry. The main cause of this existence is the lack of cooperation among actors who participate in tra catfish market. Furthermore, the lack of market information would negatively affect fish farmers in their process of estimating the number of tra catfish that should be raised. In order to deal with these problems, An Giang implemented the value chain concept into the practices of tra catfish export industry, especially the vertical linkage model - one of the approaches of value chain analysis.

In June 2011, An Giang Province was the first province in our country to implement the vertical linkage model - one of the approaches of value chain analysis into tra catfish export industry that directly promotes the association between fish farmers and enterprises to build an effective production - consumption relationship. Among those in this movement, Thuan An Production Trading and Service Company (TAFISHCO) and Viet An Joint Stock Company (ANVIFISH) are two forefront companies who implemented the model and gained several positive results in the second half of 2011 and early 2012. Therefore, measuring the effectiveness of vertical linkage between these two main actors is necessary to find out the solutions for further improvement and development of tra catfish industry. 
With this background, our study aims to measure the effectiveness of vertical linkage model between fish farmers and two companies TAFISHCO and ANVIFISH, to find out the part of the linkage that needs improving, to point out the disadvantages of non-linkage fish farmers in tra catfish market, and to create orientations for a more sustainable development. Furthermore, we also explore the effects of new rates of antidumping tariffs from the US Department of Commerce (DOC) on the vertical linkage.

Two surveys were conducted in order to provide a more objective look about the whole view of tra catfish industry through many periods of time. During March and April of 2012, in An Giang province, 70 catfish farmers were surveyed, and five in-depth interviews were conducted, of which the respondents are the directors of processing enterprises, the representatives of provincial authority, and the experts in the field. Lately, during April and June of 2013, after the new rates of antidumping duties were imposed, we conducted the second survey of 17 in-depth interviews with 12 fish farmers, four local officers, and one expert. The results given in those surveys were completely different, but had a close connection, which would be discussed in the later part of this research.

Through the comparison between famers who maintain the linkage and those who have not experienced such linkage, the advantages and long-term benefits of vertical linkage are provided in details in terms of mutual beneficial relationship, knowledge transfer, quality standards, embedded services, and payment. After analyzing collected data, we found the significant relationship between only two tested factors and vertical linkage effectiveness, which are quality standards and embedded service. The vertical linkage seemed not to be significantly affected by other remaining factors.
Besides theoretical aspects, the practical contribution of this paper is to provide a wider look at how firms and fish farmers apply the vertical linkage model in reality. In other words, we investigate whether the vertical linkage model is strong enough for widespread deployment in other areas of An Giang province. Local community, in particular the stakeholders of fish farmers and processing/export enterprises, will know how well they are performing in the linkage model and understand each other based on mutual trust and cooperation. Local authority and related associations will have a better understanding of the vertical linkage problems and come up with more appropriate solutions for further development of tra catfish farming in An Giang Province. Additionally, this paper also aims to evaluate the recent circumstance of vertical linkage model in An Giang after DOC announced the application of new rates of antidumping duties on March 15, 2013.

The remainder of this paper is structured as follows: the first part looks at the overview of tra catfish export industry in An Giang province; the second part shows detailed analysis of related factors contributing to the effectiveness of vertical linkage through both quantitative and qualitative approaches; the third part describes the change in vertical linkage after new rates of antidumping law took effect; and the last part suggests orientation for a more stable development.

\section{Literature Review}

\section{Vertical linkage concept}

The vertical linkage is one of the structural components of value chain concept - a concept from business management that was developed and popularized by Michael Porter (1985). He defined value as the amount buyers are 
willing to pay for what a firm provides and value chain as the combination of activities that work together through ideas and interdependent processes to generate value to customers (Porter, 1985).

The vertical linkage also refers to a firm's ownership of vertically related activities. The vertical linkage of the firm is strengthened when the firm's ownership and control over successive stages of its product's value chain become bigger (Khoi, 2007). Moreover, Kaplinsky and Morris (2001) suggested that the nature of vertical linkages between actors along the chain helps to define the governance structures. The powerful actor has the greatest resource and market knowledge that can influence commanding price and production standards in the value chain. This actor is known as the lead firm who sets product and process standards across the value chain and acts as coordinators or integrators of the value chain by ensuring that knowledge and information move down the chain.

In this study, the processing/export company is the lead firm that provides resources and supports, as well as sets the product and process standards to fish farmers. Fish farmers are the smaller firms that receive the resources and supports from the lead firm and need to meet lead firm's requirements on quality standards.

\section{Importance of vertical linkage}

According to Hobbs and Young (2001), effective vertical linkage relationships between firms at different levels of the value chain play a key role in supporting the upgrading capacity of the chain and can contribute to value chain competitiveness in other ways, by creating conditions that support risktaking and investment. Their research on vertical linkage in agricultural food supply chain emphasizes that vertical linkage helps the actors in agri-food productionconsumption chain respond quickly to changing food safety and quality standards.

An empirical study by Khoi (2007) about the tra catfish supply chain quality management in Vietnam has validated the relationship between vertical integration/ linkage and quality improvement. Vertical integration helps the firms minimize transaction costs, increase their resource control, and capture more rent. It also requires a high capital investment (Khoi, 2007).

Kaplinsky and Morris (2001) also mentioned three reasons that make vertical linkage become important in most of industries in the globalization context: (1) the increase in competitive advantages based on planning production and cooperation between the actors in each industry, (2) productivity and quality practices which has been becoming the survival factors when penetrating in the global market, and (3) the ability to bring stable growth for the industry relying on reputation, trust, and careful investment.

Vertical linkage practices in the current context

The emergence of vertical linkage in agricultural food industry

A research on the relationship between vertical integration/linkage and quality management of the tra catfish industry in Vietnam by Khoi (2007) tried to analyze the contribution of close vertical integration/linkage in the supply chain to the fish quality management. In the tra catfish industry, the vertical integration system between fish farmers and processing/export firms has shifted toward a long term agreement. The research pointed out that the consumers' demand for food quality and safety has been a factor in increasing vertical integration/ linkage in the food industry (Khoi, 2007). 
Another research of aquaculture value chains of African catfish in Uganda by Ssebisubi (2010) also shows that price and fish quality are the key drivers for the emergence of vertical integration/linkage in a multi-faceted value chain.

New technology, market conditions and an associated need for more managerial skills contribute to the increase in vertical coordination (Hobbs \& Young, 2001). They argued that difficulties in receiving new knowledge, meeting more strictly quality standards, and coping with financial problems motivated agri-food farmers to look for forms of linkage. In this way, the lead firm in the linkage chain will provide the embedded service to help the farmers overcome cash flow constraints.

Embedded services also include training, technical assistance, and credit for capital improvements. When agricultural producers have a secure, established relationship with their buyers, buyers may be willing to assist with long-term investments such as organic certification, equipment or postharvest handling facilities. As a result, such win-win interactions between the firms benefit the entire value chain by improving productivity, product quality, and reliability of supply.

\section{Barriers to vertical linkage}

In many value chains, there is a gap between what end markets want and what the chain actors produce due to a winlose mentality or lack of trust between vertically linked firms. As a result, the flow of information between consumers and producers is blocked. Such inefficient vertical relationships negatively affect the competitiveness of the value chain and can prevent the chain actors from effectively meeting market demand.

On the other hand, if vertical relationships are characterized by mistrust, misinformation and opportunistic behavior, the entire value chain may struggle to remain competitive. Individual firms, by conducting their vertical relationships on the basis of an adversarial win-lose way of thinking, can create negative results for themselves as well as the rest of the firms in the value chain. Vertical linkage may also result in the reduction of flexibility and the increase in bureaucratic costs (Khoi, 2007).

The linkage between fish farmers and processing/export companies in An Giang province

Under the real situation and current problems of tra catfish export industry in the provincial area, in June, 2011, An Giang Provincial People Committee requested Department of Agriculture and Rural Development (DARD) to build a plan of the production-consumption based on the export demand. To accomplish this plan, An Giang's DARD instructed two main partners in the industry - fish farmers and processing/export companies implementing the vertical linkage model by signing an agreement of cooperation. The main purpose of the agreement was to balance in supply-demand of raw tra catfish materials.

There are two main partners in a linkage chain - including fish farmers and processing export companies. After signing a linkage contract with processing/ export company, fish farmers are provided (1) technical support such as advanced farming techniques, disease prevention, quality practices, etc; (2) input support such as fingerling, fish food, medicines, chemicals, etc, with lower price than the market price and (3) knowledge support with necessary information on market, price, quality standards, etc by the linkage company. In return, the processing/ export enterprises like TAFISHCO and 
ANVIFISH will be ensured enough high quality raw fish materials for processing and export at any time. Fish farmers must ensure to meet the quality standards as the company's requirements and export market. Besides, these two partners will be supported about finance and policies by state bank system (EXIMBANK, AGRIBANK, VIETINBANK, BIDV, etc) and local authority.

Structural elements of an effective vertical linkage

According to Kaplinsky and Morris (2001), an effective vertical linkage chain is characterized by five structural factors - including mutual beneficial relationship, knowledge transfer, quality standards, embedded services and payment that described in details as follows:

(1) Mutual beneficial relationship symbiotic relationship that benefits all of the actors in a value chain is a major trait of effective vertical linkages. In this case, fish farmers and processing/export companies focus on their own core competencies and through collaborative action based on the foundation of trust, long-term joint vision, and mutual respect to improve the competitiveness of the entire chain.

(2) Knowledge transfer - Upgrading of production processes, technology, equipment, management systems, etc. is critical for the survival and growth of firms in a competitive marketplace. So, transferring knowledge and information in tra catfish industry between fish farmers and the firm is necessary to upgrade the production process and to capture new farming techniques as well as market trends.
(3) Quality standards - Well-defined, widely understood, and constantly upgraded quality standards are another defining element of effective vertical linkages. Vertically linked firms are proactive, not reactive: Processing/export companies empower and help fish farmers to understand and adopt the quality standards to meet market demand.

(4) Embedded services - The frequent provision of high-quality embedded services (where a service is provided as a part of the transaction at no extra cost) typifies effective vertical linkages.

(5) Payment - Effective vertical linkages are often accompanied by a high volume and variety of financial flows. So, the companies (buyers) must pay for fish farmers (sellers) on a negotiated time to maintain the long-term relationship and avoid occupying the capital of the seller.

\section{Methodology}

We conducted surveys of in-depth interviews and questionnaires to understand how well vertical linkages performed in the tra catfish export value chain in An Giang province. Figure 2 shows the conceptual framework that describes the whole linkage chain with two main actors, who are fish farmers and processing/export companies. Good practices of these five factors will lead to an effective vertical linkage that provides fish output guarantee and higher profits for fish farmers, as well as a stable and high quality raw fish supply for the companies contributing to promote tra catfish export industry as a whole. In contrast, bad practices of these factors will lead to mistrust, miscommunication, and failure in increasing competiveness and export performance. 


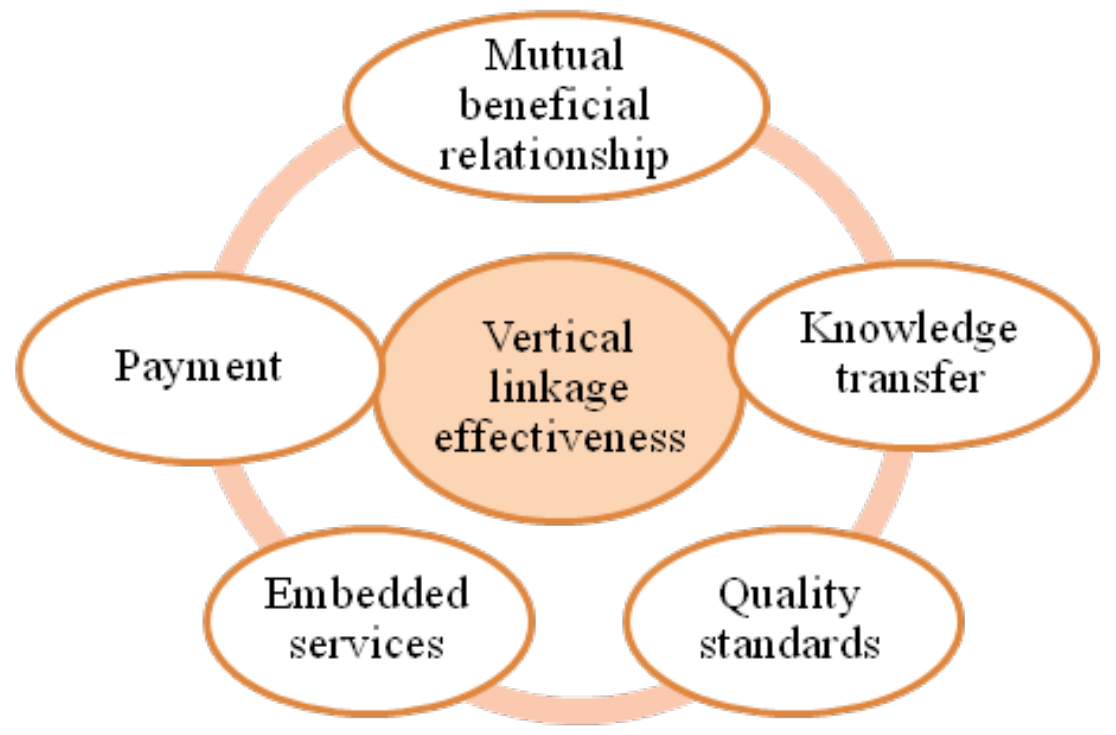

Figure 2. Structural elements of an effective vertical linkage chain

Before the questionnaires were officially delivered to individuals, the semi-structured interview was conducted to ask 10 participants about their opinions and experiences in tra catfish industry. Among the respondents, two experts were working at An Giang DARD, four experts were working at catfish processing companies, and four catfish farmers were invited. They assisted us to modify and revise the questionnaire to become easier to read and understand; thereby maintaining the research objective.

The questionnaire includes two sections. The first one contains 28 main items measured with a five-point Likert scale from 1 (strongly disagree) to 5 (strongly agree). Meanwhile, the second one suggests the open-ended questions to record farmers' voices and know what they need to improve a better vertical linkage.

Additionally, in-depth interviews were conducted with the directors of two forefront companies in the linkage movement - TAFISHCO and ANVIFISH, local authority, and experts in the field. Although the main purpose of this study is to focus on the perceived value of catfish farmers, opinions of processing/ export companies are also considered as references to gain a deeper understanding about the two-way linkage practices and companies' expectation in promoting the vertical integration. Moreover, thorough understanding and experiences of the experts in the field are highly valuable to identify current problems, to suggest orientations, and to find appropriate solutions to tra catfish vertical linkage in An Giang province.

In the first phase, we conducted the survey during March and April of 2012 in An Giang province, the number of fish farmers who were currently in a linkage was small, because the vertical linkage was just in its pilot stage. This model only attracted a small proportion of fish farmers registering as official members of the linkage chain, while the others still had doubts about its effectiveness or rejected it by many other reasons. Generally, almost all correspondents recognized that the linkages would not reach a sustainable development in the long run.

In this phase, we focused on five structural factors (Kaplinsky R. \& Morris M., 2001) that affect the effectiveness of vertical linkage: mutual beneficial 
relationship, knowledge transfer, quality standards, embeddedservices, and payment. During the interview, the interviewer must create a comfortable atmosphere to gain trust from the participants and avoid giving subjective thoughts to ensure the validity and accuracy of collected data. We surveyed 70 households living Long Xuyen city, Chau Thanh, Chau Phu, and Cho Moi districts - four districts that gain the highest annual volume of tra catfish production and export in An Giang province.

In the second phase, we conducted the survey of 17 in-depth interviews with 12 catfish farmers, four local officers, and one expert during April and June of 2013 in An Giang province after the Commerce Department of the United States announced the new rates of antidumping duties putting a charge approximately 77 cents per kilo on Vietnamese tra catfish fillets on March 15,2013 . We wanted to observe the impact of the new rates of antidumping duties on vertical linkages.

Table 1 shows descriptive data. The item is considered to be disagreed by respondents if the mean value is lower than 3.00. First of all, the means of mutual beneficial relationship vary from 2.71 to 3.97; this indicates that mutual benefits from vertical linkage are not really perceived positively by fish farmers. Secondly, the means of knowledge and information transfer range from 2.95 to 3.82. This indicates that farmers have not received the expected technology transfer from processing companies. Thirdly, the means of quality standards vary from 2.74 to 3.94 . This implies that the quality of catfish has not achieved a high standard level. Fourthly, the means of embedded services range from 2.60 to 4.70 . This implies that a process company has not created a strong support of technical guidance as well as financial assistance. Meanwhile, the item Q41 "After harvesting, the company is quite responsible for fish frozen and transporting back to the factory" has a greater mean (4.70). This is not a surprise because it is the responsibility of processing companies to keep catfish fresh. Last but not least, the means of payment vary from 2.20 to 3.20. This implies that farmers usually had to wait for a long time to receive the payment after sales. Indeed, this is one of the barriers to prevent fish farmers to join the vertical linkage as almost all farmers complain during the in-depth interviews. To sum up, the indicators of household powers have low loading means. 
Table 1. Descriptive statistics

\begin{tabular}{|c|c|c|c|}
\hline Name & Description & Mean & $\begin{array}{l}\text { Standard } \\
\text { Deviation }\end{array}$ \\
\hline & MUTUAL BENEFICIAL RELATIONSHIP & & \\
\hline Q11 & Fish output was guaranteed after harvesting & 3.9714 & 1.20351 \\
\hline Q12 & Take advantage in price negotiation & 2.7143 & 1.30931 \\
\hline Q13 & There was a voice in the linkage chain & 3.4000 & 1.10860 \\
\hline Q14 & Gain higher profits & 3.4714 & 1.23619 \\
\hline Q15 & The company obeyed the contract well & 3.3857 & 1.45754 \\
\hline \multirow[t]{2}{*}{ Q16 } & $\begin{array}{l}\text { The company had the subsidy policy on price to support fish } \\
\text { farmers when the market price goes down too low }\end{array}$ & 2.9000 & 1.25282 \\
\hline & KNOWLEDGE \& INFORMATION TRANSFER & & \\
\hline Q21 & Information on market price & 3.3857 & 1.42740 \\
\hline Q22 & Information on quality standards and food safety & 3.8286 & 1.41392 \\
\hline Q23 & Information on fish diseases & 3.6000 & 1.43860 \\
\hline Q24 & $\begin{array}{l}\text { Information on tra catfish market fluctuations during fish } \\
\text { farming }\end{array}$ & 2.9571 & 1.33445 \\
\hline Q25 & Choose fingerling & 3.6429 & 1.44499 \\
\hline Q26 & Effective techniques to fish farming & 3.0143 & 1.27964 \\
\hline Q27 & Choose fish food & 3.4143 & 1.66370 \\
\hline Q28 & Techniques of fish disease prevention & 3.5429 & 1.55746 \\
\hline \multirow[t]{2}{*}{ Q29 } & Fish farming model meets the international quality standards & 2.9571 & 1.13490 \\
\hline & QUALITY STANDARDS & & \\
\hline Q31 & $\begin{array}{l}\text { Processing/export company set the clear, specific and easy to } \\
\text { understand quality standards }\end{array}$ & 3.9429 & 1.16576 \\
\hline Q32 & Fish farmers were instructed the ways to meet these standards & 3.2286 & 1.65215 \\
\hline Q33 & Most outputs met the quality standards & 2.7429 & 1.28182 \\
\hline Q34 & Vertical linkage helped fish output's quality improved & 3.6143 & 1.39661 \\
\hline \multirow[t]{2}{*}{ Q35 } & High quality led to higher profits for fish farmers & 3.9429 & 1.35010 \\
\hline & EMBEDDED SERVICES & & \\
\hline Q41 & $\begin{array}{l}\text { After harvesting, the company is quite responsible for fish frozen } \\
\text { and Transporting back to the factory }\end{array}$ & 4.7000 & .49196 \\
\hline Q42 & $\begin{array}{l}\text { The company periodically held a team of technical staffs come } \\
\text { the fish farming places in order to check and instruct fish farmers } \\
\text { following the right directions }\end{array}$ & 2.9143 & 1.55799 \\
\hline \multirow[t]{2}{*}{ Q43 } & $\begin{array}{l}\text { The company supported the loan procedures and guarantee with } \\
\text { the bank for fish farmers }\end{array}$ & 2.6000 & 1.38731 \\
\hline & PAYMENT & & \\
\hline Q51 & The company paid for fish farmers on time as the contract & 2.2000 & 1.48031 \\
\hline Q52 & $\begin{array}{l}\text { The company paid for fish farmers in a negotiation time after } \\
\text { receiving fish }\end{array}$ & 2.9143 & 1.57648 \\
\hline \multirow[t]{2}{*}{ Q53 } & $\begin{array}{l}\text { The company paid timely to ensure that fish farmers could have } \\
\text { enough fund for the next farming season }\end{array}$ & 3.2857 & 1.56171 \\
\hline & VERTICAL LINKAGE EFFECTIVENESS & & \\
\hline Q61 & $\begin{array}{l}\text { In your opinions, participating in the vertical linkage model with } \\
\text { processing/export company is necessary }\end{array}$ & 3.8286 & 1.15434 \\
\hline Q62 & The level of supports from local authority in the linkage & 4.0714 & 1.15873 \\
\hline
\end{tabular}

Source: Data. Sample size $=70$. Using a five-point Likert scale with Minimum $=1$ (strongly disagree) and Maximum $=5$ (strongly agree) 


\section{Results}

\section{Reliability test}

This study uses a five-point Likert scale to measure factors, so it is important to find scales that are reliable. Therefore, the reliability test was taken to examine if a scale was free from random error. A scale is made up from many items, and they all measure the same underlying attribute. Hence, we wanted to check the internal consistency among items. There are several ways to measure but the most commonly statistical method is to use Cronbach's alpha $(\alpha)$. This statistic provides an indication of the average correlation among all of the items that make up the scale. Values range from 0 to 1 , with higher values meaning greater reliability. Relying on the nature and purpose of the scale, George and Mallery (2003) suggested that Cronbach's $\alpha$ is acceptable if it is above 0.6. If the "Itemtotal correlation" of any items is lower than 0.3 , those items need dropping out to increase the reliability and validity of the measurement. Based on these criteria, we drop items Q13, Q31 and Q35 after implementing the reliability test. Table 2 shows Cronbach's $\alpha$ for each construct identified and used. All Cronbach's $\alpha$ value range from 0.64 to 0.921 ; which are larger than 0.6 is acceptable.

\section{Factor analysis}

Furthermore, we used exploratory factor analysis (EFA) to assess constructs' unidimensionality. According to Hair et al. (1998), a factor loading is a criterion to ensure practical significance of EFA. A factor loading is regarded as reaching the minimum level if it is greater than 0.3 ; significance if it is greater than 0.4; and practical significance if it is greater than 0.5. Table 2 shows that all factor loadings are greater than 0.5 , thus the unidimensionality for each of the factors is obtained.

Table 2. Results of reliability test

\begin{tabular}{|l|l|c|c|}
\hline \multicolumn{1}{|c|}{ Construct } & \multicolumn{1}{|c|}{ Measurement items } & $\begin{array}{c}\text { Cronbach's } \\
\alpha\end{array}$ & $\begin{array}{c}\text { Loading } \\
\text { range }\end{array}$ \\
\hline $\begin{array}{l}\text { Mutual beneficial } \\
\text { relationship }\end{array}$ & Q11, Q12, Q14, Q15 and Q16 & 0.809 & $0.584-0.873$ \\
\hline $\begin{array}{l}\text { Knowledge and } \\
\text { information transfer }\end{array}$ & $\begin{array}{l}\text { Q21, Q22, Q23, Q24, Q25, Q26, } \\
\text { Q27, and Q29 }\end{array}$ & 0.921 & $0.669-0.895$ \\
\hline Quality standards & Q32, Q33 and Q34 & 0.713 & $0.695-0.871$ \\
\hline Embedded services & Q41, Q42 and Q43 & 0.720 & $0.684-0.920$ \\
\hline Payment & Q51, Q52 and Q53 & 0.640 & $0.732-0.794$ \\
\hline
\end{tabular}

\section{Estimated results}

Table 3 shows the estimated results. First, we saw that there is no impact of mutual beneficial relationship on the vertical linkage effectiveness. It implies that farmers have not been interested in the vertical linkage. The mutual beneficial relationship has not really attracted to farmers. A general director of a processing company stated that at beginning stage of implementing vertical linkage model, the company faced with many challenges to convince farmers to sign an agreement. The linkage chain was setup in a small scale with a limited number of participants. However, the participants often break the agreement when catfish price increased. This caused a risk on raw material supply for exporting. 
Second, we also found that the impact of knowledge is not proven. This implies that farmers have many experiences in raising catfish. In our in-depth interviews with 12 owners of households, all of them stated that they have raised catfish for more than decades. After checking their pools in early mornings, they can recognize the status of fish health in the pools. They also know how to feed, prevent, and treat common aquarium fish diseases. Generally, the benefits of knowledge and information transfers have not encouraged households to participate into the vertical linkages.

Third, the estimated coefficient of payment is 0.114 but it is at insignificant level $(\mathrm{t}$-value $=0.809<2)$. Therefore, the payment factor has no effect on the linkage assessment. Many farmers complained that exporting companies often pay late. This makes them more difficult to repay bank loans. The companies have used quick payment as a bargain tactic to lower the price when catfish need to be sold out.
Forth, the estimated coefficient of quality standards is 0.341 , at significant level less than 0.05. Therefore, this factor has a positive effect on the vertical assessment. This implies that famers who were volunteers to participate in the vertical linkage had to sign an agreement to meet quality standards for exporting markets. Farmers had responsibilities to raise fish to satisfy the requirements of the processing company to achieve quality standards of the given foreign market. For instance, these standards could include skin and meat colors, weight, length, and others.

Finally, we found that embedded services have a positive relationship with the vertical linkage. Indeed, processing companies have responsibilities for transporting, freezing, and processing services to export catfish fillets. Hence, they concern more about embedded services to guarantee the quality of catfish after taking out of the pools.

Table 3. Regression results

\begin{tabular}{|l|r|r|r|r|}
\hline \multirow{2}{*}{ Beta } & \multicolumn{2}{|c|}{$\begin{array}{c}\text { Unstandardized } \\
\text { Coefficients }\end{array}$} & $\begin{array}{c}\text { Standardized } \\
\text { Coefficients }\end{array}$ & \multirow{2}{*}{ t-value } \\
\cline { 2 - 4 } & \multicolumn{1}{|c|}{ Beta } & \multicolumn{1}{c|}{ Std. Error } & \multicolumn{1}{c|}{ Beta } & \\
\hline (Constant) & $1.386 \mathrm{E}-016$ & .081 & & .000 \\
Mutual beneficial relationship & .206 & .190 & .206 & 1.089 \\
Knowledge and information transfer & -.299 & .194 & -.299 & -1.540 \\
Quality standards & .341 & .163 & .341 & 2.088 \\
Embedded services & .472 & .150 & .472 & 3.156 \\
Payment & .092 & .114 & .092 & .809 \\
\hline
\end{tabular}

Source: Data. Dependent variable is the linkage assessment.

The effects of new rates of US antidumping duties on Vietnamese catfish

After the new rates of antidumping duties were imposed on March 15th, 2013, we conducted the second survey of 17 indepth interviews with 12 fish farmers, four local officers, and one expert during April and June, 2013, we recognized that almost all vertical linkages with processing companies to export to the US market have been deteriorated and dispersed. The most recent time US imposed heavier antidumping tariffs on Vietnam tra catfish is the $9^{\text {th }}$ period of review (POR9), which was officially announced on September $4^{\text {th }}, 2013$. The preliminary results of $9^{\text {th }}$ Antidumping Duty Administrative Review 
led to the remarkably higher tariffs than those of POR7 and POR8, although they had already been very high.

We also asked all farmers and local officers working at DARD about the development prospects of the vertical linkage model. They stated that it was too difficult to exist because there was no incentive to pursue a long-term commitment. When the second largest export market for catfish was blocked by new rates of antidumping duty from DOC, the processing companies have been facing off many difficulties to seek outlets for catfish and maintain sales. Therefore, the weaknesses of the vertical linkage model such as no mutual beneficial relationship, delay payment, no technology transfer and so on were quickly disclosed and made each partner in the linkage leave easily.

Fish farmers faced extreme difficulties when they could not sell their products after harvesting, which results from the impact of the recent rates of antidumping law decided by the DOC. At the point this law was applied, a stagnant period officially began in the export market of tra catfish. Currently it is harder than before for a farmer when exporting to the U.S. market, which has been blocked. On the other hand, if fish farmers aim at domestic markets such as wholesale markets and retail markets in MRD or large markets in Ho Chi Minh City, they could not gain profits because of the low price pressure created by the local traders in those areas. When the wholesale price is pressed under break-even price, the revenue could not cover the cost of fish farming; which seriously demotivated fish farmers. Additionally, the fish which are mainly raised to export had to follow required standards that are different from those for domestic consumption. These standards are not suited to domestic demand, thus catfish cannot attract domestic customers, causing the sharply decreasing price. In the process of interviewing fish farmers, we also raised a question about the other solutions to resolve the problem of unsold fish, which referred to why they did not sell fish to several fish-drying processing enterprises, in order to supply the market in form of dried fish. Most of the respondents stated that their fish could not meet the requirement of these enterprises due to the differences in farming conditions. First, fish aimed at being dried are raised in the dirtier environment and fed by homeprocessed food; thereby considerably lowering the cost. Second, fish used for drying must have darker skin color with thicker subcutaneous fat than exported catfish fillet. This information implied that fish farmers who previously aimed at supplying for the U.S. market are likely to be exhausted now, when all of their valuable assets such as land-use-right certificates or titles are currently kept by the bank as a collateral. Besides, they also have to bear with the high interest during their fish farming process, while their mature fish still remain unsold. In brief, the former vertical linkage at the experimental stage, which has revealed many weaknesses and limitations, is now facing difficulties in finding an output resolution in the US market. Following the fact that even larger processing corporations in this industry could not guarantee the output price for fish farmers, this vertical linkage was weakened and broken down. As a result, a plenty of tra catfish farmers are facing threat of bankruptcy.

\section{Conclusion}

Tra catfish aquaculture industry and processing for export in An Giang Province used to contribute greatly with an annual export turnover of approximately US $\$ 1.8$ billion in 2013 (Source: VASEP). It also created jobs for thousands of rural labors. However, at the moment, catfish farming 
faced many serious challenges in its development process. Global integration creates great opportunities for economic development but also increases stronger competition, which is extremely harsher when new rates of antidumping law took effect. Foreign markets have used technical barriers by raising the stringent quality standards and rigorous safety requirements that require the thoughtful investment and high financial capacity form both enterprises and fish farmers.

During previous time, the vertical linkage model of tra catfish production and consumption had achieved several positive results although it still faced many difficulties and limitations in the implementation process needs. In this study, the vertical linkage effectiveness is studied based on five factors, which are mutual beneficial relationship, knowledge transfer, quality standards, embedded services, and payment. We found that only two evaluated factors have positive relationship with the linkage effectiveness, which are quality standards and embedded service. Fish farmers who participated in linkage chain have obvious advantages compared with those who have not involved in the chain. Particularly, most of linkage farmers satisfied with higher incomes, output guarantee, financial and input support, quality instructions and embedded services processing/export companies offered. In contrast, fish farmers who were not in the linkage faced many disadvantages during tra catfish farming and selling process. Knowledge transfer from the company to fish farmers is not really effective due to the lack of technical staffs and human resource specialization. Besides, slow and rearranged payment from linkage enterprises for raw fish purchasing has been becoming a popular phenomenon, causing worry and hesitation among fish famers when deciding to enter the linkage. Especially, mistrust and miscommunication between fish farmers and processing/export companies are among the biggest barriers to the vertical linkage development and replication. These reasons threw doubt to fish farmers about the importance of vertical linkage in this globalization and integration era. Many fish farmers prefer to sell raw fish for any company offering a more competitive price in the favorite conditions when the price goes up; they do not care about the long-term relationship and fish output guarantee. Therefore, the current linkage is still not tight and unstable. In short, the vertical linkage tested was extremely weak, thus seemed to be easily broken in unfavorable conditions.

The situation was completely changed due to the appearance of new rates of antidumping law. The vertical linkage could not overcome its own weaknesses, leading to the result of being broken down. The appropriate solutions to replicate the model are, to a high extreme, necessary. Moreover, the development of fish farmers and related firms in the field are now threatened by this law. The whole tra catfish market has been seriously affected, so the existence of vertical linkage is not supported. Briefly, although the value of vertical linkage was realized, it has yet to have a chance to be strongly built. If the market recovers, this vertical linkage should be built upon a firm basis, step by step, with trust and other mentioned factors. Specifically, if foreign distributors, domestic processing companies and farmers could cooperate to create sustainable vertical linkages, current challenges will be successfully overcome.

\section{Limitation and Recommendation}

This study applied the value chain approach in tra catfish industry in An 
Giang Province, but only focused on measuring the effectiveness of the vertical linkage aspect between fish farmers and processing/export enterprise. It does not analyze the other supporting actors in the whole chain. Additionally, it does not focus on mapping the value chain as well as not go deep in analyzing cost-profit and chain value-added. The sample size is small compared to the large population of fish farmers in An Giang Province. This may result in several biases in the evaluated factors.

The establishment of vertical linkage requires the cohesion from the lead firms to smaller firms in tra catfish industry. However, the vertical linkage has just analyzed based on the stable ground of horizontal linkage, which means the firms at each level must link together first to ensure the smooth flow of information and knowledge transfer. Therefore, a study on horizontal linkage in tra catfish industry is necessary to promote this integration in the whole value chain of tra catfish industry.

Lastly, this study's results are mainly focusing on the vertical linkage before new rates of antidumping law were applied. The situation has changed, so further researches could be developed based on the new one to help solve the problems that current fish farmers and enterprises in the industry are facing.

\section{REFERENCES}

Department of An Giang Rural Development and Agriculture. Annual report 2008, 2009, 2010 and 2011. Discussion paper No. 56, Oct. 2007.

Eschborn (2007) GTZ, "Liên kết chuỗi giá trị - ValueLinks".

Hair, J. F., Anderson, R. E., Tatham, R. L., \& William, C. (1998). Black (1998), Multivariate data analysis.

Hobbs, J. E., \& Young, L. M. (2001). Vertical Linkages in Agri-foods Supply Chains in Canada and the United States. The Branch.

Jill E. and Linda M. (2001) Vertical linkage in Agri-food supply chain in Canada and the United States; Research Paper on Strategic Policy For Agriculture and Agri-Food Canada, June 2011.

Kaplinsky R. and Morris M 2001, A hand book for value chain research, Prepared for the IDRC, pp 24-37.

Le Nguyen Doan Khoi (2007) Vertical integration as an alternative governance structure of value chain quality management: The case of pangasius industry in the Mekong River Delta, Vietnam; CAS Discussion paper No. 55, Oct. 2007.

Le Nguyen Doan Khoi 2007, Description of the pangasius value chain in Vietnam, CAS M4P (2007), Market for the poor handbook - Tools of value chain analysis.

Porter, M. E. (1985) Competitive Advantage: Creating and Sustaining Superior Performance, New York: Free Press.

Ssebisubi, M., Ögmundur, K., \& Helgi, G. (2012). The Value Chain of Farmed African Catfish in Uganda.

Statistical Year Book of An Giang 2008, 2009, 2010 and 2011. 